\title{
Improving the range of industrial plantings of grapes due to introduced clones
}

\author{
Dmitry Yermolin ${ }^{1, *}$, Zinaida Kotolovets $^{2}$, Natalia Studennikova ${ }^{2}$, Galina $_{\text {Yermolina }}{ }^{1}$, and \\ Daria Zadorozhnaya ${ }^{1}$ \\ ${ }^{1}$ V.I. Vernadskiy Crimean Federal University, Prospekt Vernadskogo 4, 295033, Simferopol, \\ Republic of Crimea, Russia \\ ${ }^{2}$ Magarach All-Russia National Research Institute for Viticulture and Wine-Making, Kirov str. 31, \\ 298637, Yalta, Republic of Crimea, Russia
}

\begin{abstract}
Studies have shown that the clone of the Chardonnay R-10 against the background of the standard variety is characterized by higher agrobiological indicators: fruit bearing coefficient, average cluster weight, the yield from the bush exceeds the control by 1.3 times. The shoot productivity in the wet mass of the bunch in the clone of the Chardonnay R10 variety is characterized as "high". The clone of the Sauvignon green R-3 variety showed high shoot fertility, the average mass of the bunch in the clone reaches $165.3 \pm 2.2 \mathrm{~g}$, exceeding the control 1.15 times, the yield from the bush reaches $4.02 \pm 0.1 \mathrm{~kg}$, exceeding the standard grade by $1 \mathrm{~kg}$. The shoot productivity in the wet mass of the bunch is characterized as "high". The average weight of a bunch in a clone of Muscat white R-3 variety reaches $275.3 \pm 2.03 \mathrm{~g}$, which is 95 grams more than the control $(180.0 \pm$ $3.2 \mathrm{~g}$ ). The yield from the bush is $4.49 \pm 0.2 \mathrm{~kg}$, exceeding the standard variety by 1.7 times. The productivity of the shoot is characterized as "very high." The degree of variation of characters in clone populations of the Chardonnay varieties $\mathrm{R}-10(\mathrm{~V}=2.4-9.8 \%)$, Sauvignon green $\mathrm{R}-3(\mathrm{~V}=1.8$ $8.7 \%)$, White Muscat $\mathrm{R}-3(\mathrm{~V}=1.2-9.3 \%)$ are characterized as weak, which indicates the genetic homogeneity of the studied clone populations under specific growing conditions. Technological evaluation showed that wine materials produced from introduced Chardonnay R-10 clones, Sauvignon green R-3 and White Muscat R-3 excel in quality indicators wine materials produced from standard varieties.
\end{abstract}

\section{Introduction}

Currently, the actual direction for winemaking is the introduction of clones of classical European grape varieties in order to improve the varietal composition of a particular viticulture zone [1]. Over the past decades, on the farms of the State Unitary Enterprise "PJSC Massandra", vineyards are laid with high-yielding clones of the foreign selection "Cooperative nursery Raushedo VCR" that are resistant to fungal etiology. The introduction of new clones of grape varieties in the Crimea helps to increase the yield of vineyards. It is advisable to make up for obtaining high-quality raw materials for winemaking, leveling the

\footnotetext{
*Corresponding author: dimayermolin@mail.ru
} 
deficit of wine materials for the production of table and sparkling wines by using promising clones of the Chardonnay, Sauvignon, Muscat varieties [2-14].

The purpose of the work is to study the agrobiological and technological parameters of the introduced clones of industrial grape varieties in the conditions of the Alushta Valley.

\section{Materials and methods}

The studies were conducted in 2017-2019. in industrial vineyards, a branch of Alushta (Alushta) of the State Unitary Enterprise of the Republic of Kazakhstan PJSC Massandra in plantations of varieties and introduced clones. A clone of the variety Muscat white R-3 2009 planting, the variety Muscat white (control) 2006 planting. Clone cultivar Chardonnay R-10 2009 planting, control cultivar 2010 planting. Clone varieties Sauvignon green R-3 2008 planting, variety control 2010 planting. Layout on sections $3 \times 1.25 \mathrm{~m}$, formation - AZOS-1 spiral cordon with a free growth location, sections without irrigation. The Muscat white R-3 clone varieties account for $4.44 \%$ (20.31 ha) of the total area occupied by technical varieties, the Chardonnay R-10 clone accounts for $2.14 \%$ (9.77 ha), and the specific the weight of a clone of Sauvignon green R-3 is 1\% (4.46 ha). Wine materials from varieties and clones. In the work, methods of analysis generally accepted in viticulture and enochemistry were used. The climate of the Alushta southern coast is sub-Mediterranean: arid, hot, with very mild winters. The frost-free period lasts an average of 234 days a year; snow is very rare. The average temperature of July, the warmest month of the year in Alushta, $+23.3^{\circ} \mathrm{C}$; the coldest month, February, $-+2.9^{\circ} \mathrm{C}$. The absolute minimum is $-18^{\circ} \mathrm{C}$, the absolute maximum is + $39^{\circ} \mathrm{C}$. The average annual air temperature is $+12.3^{\circ} \mathrm{C}$. The annual sum of active temperatures (above $+10^{\circ} \mathrm{C}$ ) reaches $3650-3714^{\circ} \mathrm{C}$, which contributes to the growth of indigenous and introduced plants. Alushta is characterized by a lack of precipitation: $427 \mathrm{~mm}$ of precipitation falls during a year. Winter precipitation prevails [15].

The grapes were processed according to the white method in the conditions of microviniculture. The output of the wort was no more than 65 dal of 1 ton of grapes. Fermentation was carried out on a pure yeast culture. At the end of the fermentation, the wine materials were removed from the yeast, their sulfitation was carried out at the rate of $25 \mathrm{mg}$ / dm3.

\section{Results and discussions}

Table 1 presents the agrobiological indicators of white technical grape varieties and their clones, average for 2017-2019.

Studies have shown that a clone of the Chardonnay R-10 against the background of the standard variety is characterized by a higher fruiting coefficient (1.23). The average mass of a bunch of clones is $173.7 \pm 1.5 \mathrm{~g}$, exceeding the control by 1.12 times, the yield from the bush reaches $3.87 \pm 0.3 \mathrm{~kg}$, exceeding the control by 1.3 times. The shoot productivity by fresh weight of the bunch in a clone of the Chardonnay R-10 variety is $213.8 \pm 4.4 \mathrm{~g} /$ shoot and is characterized as "high" compared to the control, in which this indicator is defined as "average" - $165.0 \pm 3,9 \mathrm{~g} /$ shoot. 
Table 1. Agrobiological indicators of white technical grape varieties and their clones, 2017-2019.

\begin{tabular}{|c|c|c|c|c|c|c|c|c|c|c|}
\hline $\begin{array}{c}\text { Sample } \\
\text { Name }\end{array}$ & 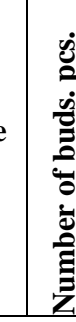 & 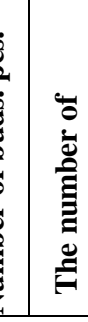 & 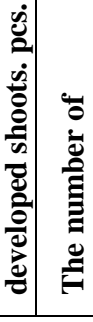 & 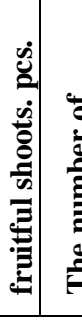 & 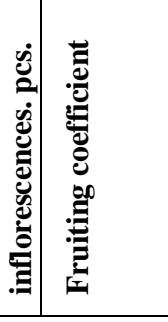 & 营 & 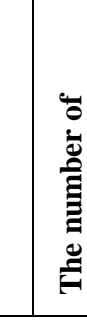 & 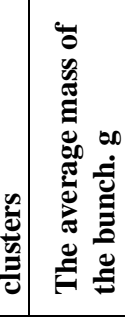 & 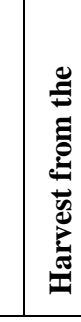 & 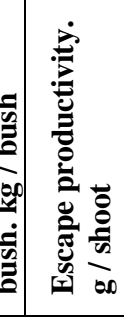 \\
\hline \multicolumn{11}{|c|}{ Chardonnay } \\
\hline $\begin{array}{c}\text { Cont } \\
\text { rol } \\
\text { Sam } \\
\text { ple }\end{array}$ & $\begin{array}{l}30 \pm \\
1.16\end{array}$ & $\begin{array}{c}25.7 \pm \\
1.2\end{array}$ & $\begin{array}{c}19.3 \pm 1 \\
5\end{array}$ & $\begin{array}{c}27.3 \pm \\
1.4\end{array}$ & $1.06 \pm 0.1$ & $1.4 \pm 0.06$ & $\begin{array}{c}18.7 \pm \\
1.5\end{array}$ & $\begin{array}{c}155.7 \pm \\
1.5\end{array}$ & $\begin{array}{l}2.91 \\
\pm 0.3\end{array}$ & $\begin{array}{c}165 \pm 3 \\
9\end{array}$ \\
\hline V. $\%$ & 6.6 & 8.1 & 13.0 & 10.0 & 14.2 & 5.6 & 13.4 & 2.8 & 15.5 & 4.0 \\
\hline $\begin{array}{l}\text { clone } \\
\text { R-10 }\end{array}$ & $\begin{array}{l}27.7 \\
\pm 0.9 \\
\end{array}$ & $\begin{array}{c}24.7 \pm \\
0.7 \\
\end{array}$ & $\begin{array}{c}20.0 \pm 1 \\
2\end{array}$ & $\begin{array}{r}30.3+ \\
0.9\end{array}$ & $1.23 \pm 0.1$ & $1.5 \pm 0.06$ & $\begin{array}{c}22.3 \pm \\
1.2\end{array}$ & $\begin{array}{c}173.7 \pm \\
1.5 \\
\end{array}$ & $\begin{array}{l}3.87 \\
\pm 0.3 \\
\end{array}$ & $\begin{array}{c}213.8 \pm \\
4.4 \\
\end{array}$ \\
\hline V. $\%$ & 5.5 & 4.6 & 9.8 & 5.0 & 8.1 & 4.6 & 9.3 & 2.4 & 9.7 & 3.5 \\
\hline \multicolumn{11}{|c|}{ Sauvignon Green } \\
\hline $\begin{array}{c}\text { Cont } \\
\text { rol } \\
\text { Sam } \\
\text { ple } \\
\end{array}$ & $\begin{array}{l}23.0 \\
\pm 3.7\end{array}$ & $\begin{array}{l}21.3 \\
\pm 2.0\end{array}$ & $\begin{array}{l}18.6 \\
\pm 1.8\end{array}$ & $\begin{array}{l}26.4 \\
\pm 1.5\end{array}$ & $1.24 \pm 0.1$ & $1.42 \pm 0.1$ & $\begin{array}{l}21.7 \\
\pm 1.8\end{array}$ & $\begin{array}{c}143.0 \pm \\
3.2\end{array}$ & $\begin{array}{c}3.1 \pm \\
0.2\end{array}$ & $\begin{array}{c}177.3 \pm \\
5.5\end{array}$ \\
\hline V. $\%$ & 27.7 & 16.5 & 18.9 & 9.6 & 14.3 & 15.2 & 14.1 & 3.9 & 12.7 & 5.3 \\
\hline $\begin{array}{c}\text { clone } \\
\text { R-3 }\end{array}$ & \begin{tabular}{|l|}
25.0 \\
\pm 1.2 \\
\end{tabular} & \begin{tabular}{|l|}
23.0 \\
\pm 1.2 \\
\end{tabular} & $\begin{array}{l}20.3 \\
\pm 0.9 \\
\end{array}$ & $\begin{array}{l}32.0 \\
\pm 1.2 \\
\end{array}$ & $\begin{array}{c}1.39 \pm 0.0 \\
2 \\
\end{array}$ & $1.58 \pm 0.02$ & $\begin{array}{l}24.3 \\
\pm 0.3 \\
\end{array}$ & $\begin{array}{c}165.3 \pm \\
2.2 \\
\end{array}$ & $\begin{array}{l}4.02 \\
\pm 0.1 \\
\end{array}$ & $\begin{array}{c}229.7 \pm \\
2.3 \\
\end{array}$ \\
\hline V. $\%$ & 8.0 & 8.7 & 7.5 & 6.3 & 2.5 & 1.6 & 2.4 & 2.3 & 5.2 & 1.8 \\
\hline \multicolumn{11}{|c|}{ Muscat white } \\
\hline $\begin{array}{c}\text { Cont } \\
\text { rol } \\
\text { Sam } \\
\text { ple }\end{array}$ & $\begin{array}{l}23.7 \\
\pm 1.5\end{array}$ & $\begin{array}{l}21.0 \\
\pm 2.1\end{array}$ & $\begin{array}{l}17.3 \\
\pm 1.2\end{array}$ & $\begin{array}{l}18.0 \\
\pm 1.2\end{array}$ & $\begin{array}{c}0.86 \pm 0.0 \\
4\end{array}$ & $1.04 \pm 0.04$ & $\begin{array}{l}14.3 \\
\pm 1.8\end{array}$ & $\begin{array}{c}180.0 \pm \\
3.2\end{array}$ & $\begin{array}{l}2.57 \\
\pm 0.3\end{array}$ & $\begin{array}{c}154.8 \pm \\
5.6\end{array}$ \\
\hline V. $\%$ & 10.6 & 13.9 & 12.0 & 11.1 & 8.1 & 7.0 & 2.4 & 2.3 & 5.2 & 1.8 \\
\hline $\begin{array}{c}\text { clone } \\
\mathrm{R}-3\end{array}$ & $\begin{array}{r}26.0 \\
\pm 1.2 \\
\end{array}$ & $\begin{array}{l}22.3 \\
\pm 0.9 \\
\end{array}$ & $\begin{array}{r}18.3 \\
\pm 0.9 \\
\end{array}$ & $\begin{array}{l}24.7 \\
\pm 0.9 \\
\end{array}$ & $1.11 \pm 0.04$ & $1.35 \pm 0.09$ & $\begin{array}{r}14.3 \\
\pm 1.8 \\
\end{array}$ & $\begin{array}{c}180.0 \pm \\
3.2 \\
\end{array}$ & $\begin{array}{l}2.57 \\
\pm 0.3 \\
\end{array}$ & $\begin{array}{c}154.8 \pm \\
5.6 \\
\end{array}$ \\
\hline V. $\%$ & 7.6 & 6.8 & 8.3 & 6.1 & 6.9 & 10.9 & 9.3 & 1.2 & 7.9 & 6.2 \\
\hline
\end{tabular}

The clone of the Sauvignon green R-3 variety showed high shoot fertility: fruit bearing coefficient averaged 1.39, exceeding the control by 1.12 times. The average mass of a bunch of clones reaches $165.3 \pm 2.2 \mathrm{~g}$, exceeding the control by 1.15 times, the yield from the bush reaches $4.02 \pm 0.1 \mathrm{~kg}$, exceeding the standard variety by $1 \mathrm{~kg}$. The shoot productivity by fresh weight of the bunch in the clone of Sauvignon green R-3 is $229.7 \pm 2.3 \mathrm{~g} /$ shoot and is characterized as "high" compared to the control, in which this indicator is defined as "average" - $177.3 \pm 5.5 \mathrm{~g} /$ shoot.

The average weight of a bunch in a clone of Muscat white R-3 variety reaches $275.3 \pm$ $2.03 \mathrm{~g}$, which is 95 grams more than the control $(180.0 \pm 3.2 \mathrm{~g})$. The yield from the bush is $4.49 \pm 0.2 \mathrm{~kg}$, exceeding the standard variety by 1.7 times. The shoot productivity in terms 
of fresh weight of the bunch in the clone of the Muscat white R-3 variety is $305.5 \pm 11.1 \mathrm{~g} /$ shoot and is characterized as "very high" compared to the control, in which this indicator is defined as "average" - $154.8 \pm 5.6 \mathrm{~g} /$ shoot.

In grapes, quantitative variability of biological and economic characteristics is clearly expressed. The conducted variational analysis showed (Table 1) that the degree of variation of characters in the clone populations of varieties Chardonnay $\mathrm{R}-10(\mathrm{~V}=2.4-9.8 \%)$, Sauvignon green $\mathrm{R}-3(\mathrm{~V}=1.8-8.7 \%)$, White $\mathrm{R}-3$ Muscat $(\mathrm{V}=1.2-9.3 \%)$ are characterized as weak, which indicates the genetic homogeneity of the studied clone populations under specific growing conditions. The degree of variability of most characters in populations of standard varieties is characterized as average, which indicates the heterogeneity of the population and the ability to further isolate new biotypes.

Crucial in the assessment of grape varieties and clones is given to the characterization of the resulting wine products. In this regard, wine materials for the production of table wines were prepared from the investigated clones and control varieties.

Table 2. Physico-chemical and organoleptic characteristics of wine materials from white technical grape varieties and their clones, 2017-2019.

\begin{tabular}{|c|c|c|c|c|c|c|c|}
\hline $\begin{array}{c}\text { Sample } \\
\text { Name }\end{array}$ & 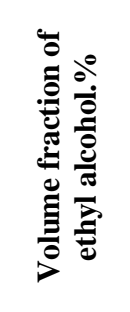 & 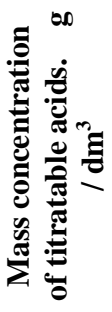 & 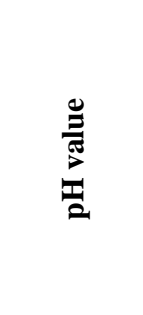 & 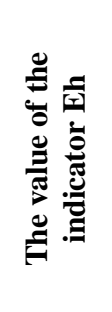 & 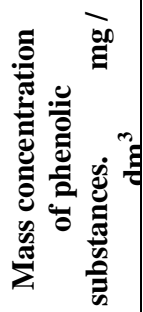 & 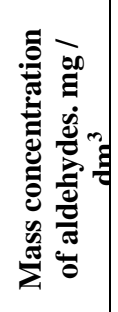 & 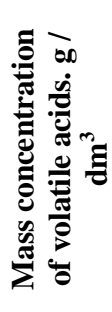 \\
\hline \multicolumn{8}{|c|}{ Chardonnay } \\
\hline $\begin{array}{l}\text { Control } \\
\text { Sample }\end{array}$ & $12.4 \pm 0.3$ & $6.2 \pm 0.5$ & $3.19 \pm 0.07$ & $184 \pm 23$ & $250 \pm 20$ & $61 \pm 17$ & $0.6 \pm 0.2$ \\
\hline $\begin{array}{l}\text { clone R- } \\
10\end{array}$ & $12.6 \pm 0.2$ & $6.8 \pm 0.4$ & $3.13 \pm 0.09$ & $193 \pm 19$ & $220 \pm 15$ & $56 \pm 19$ & $0.4 \pm 0.3$ \\
\hline \multicolumn{8}{|c|}{ Sauvignon Green } \\
\hline $\begin{array}{l}\text { Control } \\
\text { Sample }\end{array}$ & $11.4 \pm 0.6$ & $5.9 \pm 0.6$ & $3.25 \pm 0.11$ & $207 \pm 27$ & $240 \pm 20$ & $39 \pm 10$ & $0.7 \pm 0.2$ \\
\hline clone R-3 & $11.8 \pm 0.4$ & $6.3 \pm 0.4$ & $3.12 \pm 0.07$ & $195 \pm 22$ & $215 \pm 10$ & $26 \pm 13$ & $0.3 \pm 0.2$ \\
\hline \multicolumn{8}{|c|}{ Muscat white } \\
\hline $\begin{array}{l}\text { Control } \\
\text { Sample }\end{array}$ & $11.6 \pm 0.2$ & $6.2 \pm 0.4$ & $3.29 \pm 0.10$ & $193 \pm 21$ & $270 \pm 25$ & $76 \pm 27$ & $0.5 \pm 0.3$ \\
\hline clone R-3 & $11.9 \pm 0.2$ & $6.4 \pm 0.3$ & $3.23 \pm 0.12$ & $206 \pm 17$ & $250 \pm 25$ & $61 \pm 19$ & $0.2 \pm 0.1$ \\
\hline
\end{tabular}

An analysis of the data presented in table 2 indicates that, according to the volume fraction of ethyl alcohol, the mass concentration of titratable acids, and the mass concentration of volatile acids, the studied wine materials met the requirements of normative and technical documentation. The value of the volume fraction of ethyl alcohol in the Chardonnay R-10 wine material exceeded the value of the control sample by $2 \%$, the mass concentration of titratable acids by $9 \%$, and the mass concentration of volatile acids was $30 \%$ 
lower. For wine material Sauvignon green R-3, these values were 3\%, $6 \%$ and $60 \%$; for wine material Muscat white R-3 - 3\%, 3\% and 60\%.

By mass concentration of phenolic substances, control and experimental wine materials met the requirements for the production of high-quality table wines. The mass concentration of phenolic substances in the control sample of Chardonnay wine material exceeded the value of Chardonnay R-10 wine material by $12 \%$. For wine materials Sauvignon green, this value was $6 \%$, White Muscat $-8 \%$.

The $\mathrm{pH}$ value of Chardonnay wine material (control) was $3.19 \pm 0.07$, of Chardonnay R10 wine material - $3.13 \pm 0.09$; Sauvignon green control $3.25 \pm 0.11$, Sauvignon green R-3 $3.12 \pm 0.07$; White Muscat (control) 3.29 \pm 0.10 White Muscat R-3 3.23 \pm 0.12 .

The value of the Eh index for all samples was in the range of 172-234. Mass concentration of aldehydes 13-106 mg / dm3.

Tasting assessments of the studied wine materials are presented in Figure 1

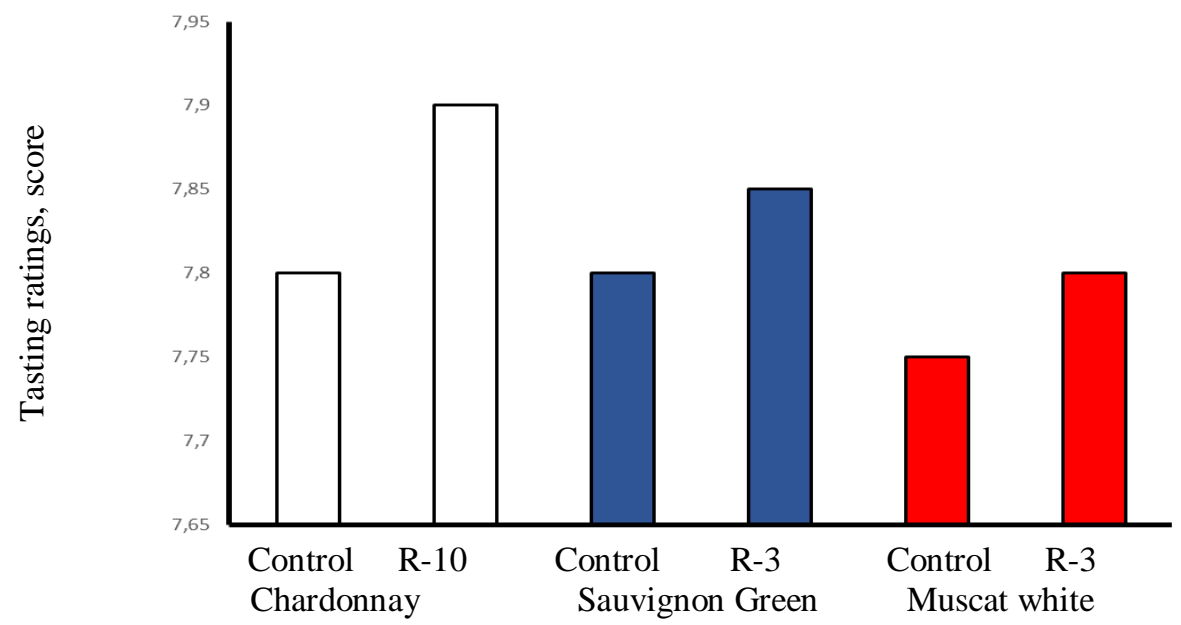

Fig. 1. Tasting assessments of the studied wine materials.

Figure 1 shows that the tasting estimates of wine materials produced from introduced clones were higher than wine materials from standard varieties. For Chardonnay R-10 wine materials, the aroma was characterized by floral tones with hints of exotic fruits, Sauvignon green R-3 - floral-fruit tones with hints of currant leaf, White Muscat R-3 - fruit tones with hints of lime. On the palate, all samples were harmonious, light, balanced with a long varietal finish. Sweet wine materials were prepared from a control sample of White Muscat grapes and White Muscat R-3 clone (mass concentration of sugars was $55 \mathrm{~g} / \mathrm{dm} 3$ ) physico-chemical parameters are shown in Table 3.

Table 3. Physico-chemical and organoleptic characteristics of sweet wine materials from white technical grape varieties and their clones, 2017-2019.

\begin{tabular}{|l|c|c|}
\hline \multicolumn{1}{|c|}{ Index } & White Muscat & White Muscat R-3 \\
\hline Volume fraction of ethyl alcohol. \% & $10.4 \pm 0.9$ & $11.0 \pm 0.7$ \\
\hline $\begin{array}{l}\text { Mass concentration of titratable } \\
\text { acids. g / dm3 }\end{array}$ & $5.0 \pm 0.4$ & $5.4 \pm 0.6$ \\
\hline $\begin{array}{l}\text { Mass concentration of volatile acids. } \\
\text { g dm3 }\end{array}$ & $0.7 \pm 0.2$ & $0.5 \pm 0.2$ \\
\hline $\begin{array}{l}\text { Mass concentration of glycerin. g / } \\
\text { dm3 }\end{array}$ & $6.6 \pm 0.7$ & $7.2 \pm 0.6$ \\
\hline Tasting ratings. score & $7.80 \pm 0.5$ & $7.85 \pm 0.3$ \\
\hline
\end{tabular}


The values of the volume fraction of ethyl alcohol, the mass concentration of titratable acids, the mass concentration of glycerin of the white Muscat wine material R-3 exceeded the values of the white Muscat wine material (control). The mass concentration of volatile acids in the wine material produced from Clone Muscat white R-3 was lower than in the wine material developed from the control variety (table 3).

Organoleptic evaluation showed that sweet wine materials developed from white Muscat R-3 are higher quality than wine materials developed from white Muscat white (control).

\section{Conclusions}

Presented introduced clones of classical grape varieties cultivated in the Alushta Valley surpass standard varieties in terms of cluster weight, yield from a bush, and shoot productivity in terms of fresh cluster mass, which gives grounds for their further propagation and introduction. The technological assessment also showed that wine materials produced from introduced Chardonnay R-10 clones, Sauvignon green R-3 and White Muscat R-3 are superior in quality indicators to wine materials produced from standard varieties.

\section{References}

1. Z.V. Kotolovets, D.V. Yermolin, G.V. Yermolina, Magarach. Viticulture and $\begin{array}{llllll}\text { winemaking } & \mathbf{3}, & 16-17 & \text { (2017) } & \text { https:// elibrary.ru/ }\end{array}$ download/elibrary_30016935_49292275.pdf

2. M.M. Anderson, R.J. Smith, M.A. Williams, J.A. Wolpert, Am J Enol Vitic. 59, 73-77 (2008) https://www.ajevonline.org/content/59/1/73

3. V. Dimovska, K. Beleski, K. Boskov, V. Ivanova, F. Ilieva, International Journal of Agronomy and Plant Production 4(6), 1143-1147 (2013) doi: 10.7251/AGREN1201095D

4. V. Dimovska, E. Sofijanova, F. Ilieva, Science \& Technologies III(6), 9-14 (2013) https://www.researchgate.net/publication/258642573

5. N. Sweet, FPS Grape Program Newsletter October, 17-31 (2010), http://cemendocino.ucanr.edu/files/63273.pdf

6. R. Peiró, J. X. Soler, A. Crespo, C. Jiménez, F. Cabello, Spanish Journal of Agricultural Research 4(6), 1143-1147 (2013) doi: 10.5424/sjar/2018162-12537

7. I. Dumitru, C. Necula, C. Popa, S. Iordache, P. C. Patic, Bulletin UASVM Horticulture 66, 267-271 (2009) http://journals.usamvcluj.ro/index.php/horticulture/article/ view/3850/3868

8. K.A. Kahramana, G. Söylemezoğlub, New Zealand Journal of Crop and Horticultural Science 42(2), 77-86 (2014) doi: 10.1080/01140671.2013.851092

9. M. Roach, D. Johnson, J. Bohlmann, H.J. Van Vuuren, S. Jones, I. Pretorius, S. Schmidt, A. Borneman, PLOS Genetics, 1-24 (2018) doi: 10.1371/journal.pgen.1007807

10. D.V. Ermolin, D.S. Zadorozhnaya, G.V. Ermolina, Vestn. KrasGAU 5, 208-213 (2018) https://elibrary.ru/download/elibrary_36588409_65564401.pdf

11. J.A. Greena, W.V. Parrb, J. Breitmeyerb, D. Valentinc, R. Sherlockb, Food Research International 44(9), 2788-2797 (2011) doi: 10.1016/j.foodres.2011.06.005

12. M. Fidelibus, P. Christensen, D. Katayama, P. Verdenal, Am. J. Enol. Vitic. 57(4), 503506 (2006) http://www.ucanr.org/sites/intvit/files/77321.pdf 
13. D. Vujovi'c, R. Maleti'c, J. Popovi'c-Đordevi'c, B. Pejinb, R. Risti, Journal of the Science of Food and Agriculture 97(2) (2016) doi: 10.1002/jsfa.7769

14. K. Šuklje, G. Antalick, A. Buica, J. Langlois, Z.A. Coetzee, J. Gouot, J. Sci. Food. Agric. 96, 915-926 (2015) doi: 10.1002/jsfa.7165

15. M.N. Borisenko, N.L. Studennikova, Z.V. Kotolovets, P.V. Beisel, Magarach. $\begin{array}{llllll}\text { Viticulture and winemaking } & \text { 2, } & 8-9 & \text { (2015) https:// }\end{array}$ elibrary.ru/download/elibrary_23644834_74558083.pdf 